\title{
MECHANICAL PROPERTIES PREDICTION OF IG-110 GRAPHITE BY NON DESTRUCTIVE INSPECTION USING ULTRASONIC METHOD
}

\author{
R. Himawan, M. Haryanto and M. Budi Setiawan \\ Pusat Teknologi dan Keselamatan Reaktor Nuklir (PTRKN) - BATAN \\ Kawasan Puspiptek, Serpong, Tangerang Selatan, 15314 \\ E-mail: roziqh@batan.go.id
}

Revised: 21 March 2019

Accepted: 28 March 2019

\begin{abstract}
MECHANICAL PROPERTIES PREDICTION OF IG-110 GRAPHITE BY NON DESTRUCTIVE INSPECTION USING ULTRASONIC METHOD. The core structure of high temperature gas cooled reactor is the most important part of the reactor which its integrity must be ensured during operation stage. The structure of reactor core must ensure the position of fuel to be kept in its position, to ensure the control rods can get into the guiding canal, and to ensure the flow of the gas coolant. One of the stressor of the graphite material degradation is neutron exposure. The impact of neutron exposure is the change in mechanical properties such as modulus of elasticity. In order to ensure the integrity of the materials, an in-service non-destructive inspection is implemented. The aim of this study is to develop non-destructive inspection method in order to predict mechanical properties of graphite materials. Inspections were done using Ultrasonic Flaw Detector with $35 \times 35 \times 55[\mathrm{~mm}]$ block-shaped specimens made of graphite IG-110. Two types of transducer were used to generate longitudinal and transversal waves with the same frequency of $5 \mathrm{MHz}$. Two mechanical properties were predicted, that are isotropic characteristic and the modulus of elasticity. The predicted value of the modulus of elasticity was verified by conducting compressive tests using $10 \times 10 \times 10$ [mm] cube specimens. According to the ultrasonic propagation velocities resulted from ultrasonic inspection results showed that the graphite IG-110 is an isotropic material. From the calculation of the modulus of elasticity based on measurement results of transversal and longitudinal waves propagation, IG-110 graphite has a value of modulus of elasticity of $9.1 \mathrm{GPa}$. Compared to the modulus of elasticity measured from compressive test, this value was $10 \%$ lower. It can be concluded that the ultrasonic non-destructive inspection can be used to predict mechanical properties of the IG-110 graphite.
\end{abstract}

Keywords: Non-destructive test, Ultrasonic method, Ultrasonic Flaw Detector, Mechanical properties, IG-110 graphite

\begin{abstract}
ABSTRAK
PREDIKSI SIFAT MEKANIK GRAFIT IG-110 SECARA TAK MERUSAK MENGGUNAKAN METODE ULTRASONIK. Struktur teras reaktor berpendingin gas temperatur tinggi merupakan bagian terpenting dari reaktor yang integritasnya harus terjamin selama masa operasi. Struktur teras reaktor harus menjamin posisi bahan bakar agar tetap pada posisinya, menjamin batang kendali dapat masuk ke dalam kanal penuntun, dan menjamin adanya aliran gas pendingin. Salah satu pemicu degradasi material grafit IG-110 sebagai bahan struktur teras reaktor adalah paparan neutron. Dampak paparan neutron adalah perubahan sifat mekanik seperti modulus elastisitas. Dalam rangka memastikan integritas material, dilaksanakan In-service inspection secara tak merusak. Penelitian ini bertujuan untuk mengembangkan metode uji tak merusak dalam rangka memprediksi sifat mekanik material grafit. Pengujian dilakukan menggunakan alat Ultrasonic Flaw Detector terhadap spesimen berbentuk balok dengan ukuran $35 \times 35 \times 55$ [mm] terbuat dari material grafit IG110. Dua jenis transducer digunakan untuk memancarkan gelombang longitudinal dan transversal dengan frekuensi sama yaitu $5 \mathrm{MHz}$. Sifat mekanik yang diestimasi adalah sifat isotropis dan nilai modulus elastisitas. Hasil estimasi nilai modulus elastisitas diverifikasi melalui uji tekan terhadap spesimen kubus berukuran $10 \times 10 \times 10$ $[\mathrm{mm}]$. Dari hasil pengukuran cepat rambat gelombang ultrasonik pada material grafit menunjukkan bahwa grafit IG-110 merupakan material isotropis. Dan dari perhitungan nilai modulus elastisitas berdasarkan hasil
\end{abstract}




\begin{abstract}
pengukuran cepat rambat gelombang transversal dan longitudinal, material grafit yang digunakan pada penelitian ini memiliki nilai modulus elastisitas sebesar 9,1 GPa. Apabila dibandingkan dengan nilai modulus elastisitas yang dihasilkan dari uji tekan, nilai ini 10\% lebih rendah. Dari hasil-hasil ini dapat disimpulkan bahwa uji tak merusak metode ultrasonik dapat digunakan untuk memprediksi sifat mekanik grafit IG-110.
\end{abstract}

Kata kunci: Uji tak merusak, Metode ultrasonik, Ultrasonic Flaw Detector, Sifat mekanik, Grafit IG-110

\section{INTRODUCTION}

High Temperature Gas Cooled Reactor (HTGR) is one of innovative reactors which have its inherent safety [1]. In the case of loss of cooling, the chain nuclear fission reaction will be stopped by a negative coefficient of the reactor, so that the reactor's temperature will drop. This characteristic allows the reactor inherent safety without operator interference. The high temperature operation of HTGR does not allow the use of metallic materials as the constituent structure of the reactor core. A nuclear grade graphite material is used instead. In addition of being used as structure materials, graphite is also functioning as a moderator and reflector [1].

As a structural material, graphite reactor core will receive high neutron exposure, high temperatures and loads. Therefore, the fracture behavior of the graphite material has a strong impact to the safety of the reactor as a whole[2]. Neutron exposure is a main trigger for material aging which is not occurred in non-nuclear power plants. The neutron exposure affects the geometry, modulus elasticity, expansion coefficient, and the thermal conductivity[3]. In order to ensure the integrity of the core structure, in-service inspection (ISI) is conducted to find out whether there are defects in graphite. Based on the condition of physical properties changes, mechanical properties changes and thermal properties changes of graphite material due to neutrons exposure, a mechanical characteristics prediction it needed to be conducted in the ISI procedures.

Researches have been widely conducted for predicting material modulus of elasticity both by nondestructive and semi non-destructive methods. Ultrasonic method has been successfully used for predicting modulus of elasticity of glass and concrete materials [4,5]. Method of nano indentation successfully used to determine modulus of elasticity of neutron irradiated fuel cladding material [6]. Interferometry method can be used to determine the modulus of elasticity of the Thermal Barrier Coating materials [7]. Meanwhile, the determination of the modulus of elasticity of concrete material can also be done by the method of eigen frequencies [8]. Among the methods that have been outlined, ultrasonic method is a method that is simple, inexpensive, and easy to do and the results can be seen immediately. In addition, ultrasonic method can be applied to detect damage on various materials. Ultrasonic method shows a good correlation between the wave propagation and the compression load value on the concrete materials [9].
Damage to the plates of the polyethylene material can be detected effectively using ultrasonic method [10]. Concrete quality stability condition can be measured by non-destructive ultrasonic method [11]. Damage of the composite material can be found using ultrasonic method.

Regarding to the graphite IG-110, various mechanical properties are determined by destructive tests such as creep test, flexural test, and compressive test. In term of In-service Inspection, these methods couldn't be applied. Hence, a non-destructive method for determining the mechanical properties is needed. Previous researches have never been reported the application of ultrasonic method for predicting the mechanical properties of IG-110 nuclear grade graphite. Therefore, the aim of this study is to develop a prediction method of mechanical properties for IG-110 nuclear grade graphite. In order to ensure the results obtained from ultrasonic method, a destructive tests were conducted using the same material to validate them. In addition, this method will be implemented in the conduction of ISI to detect defects in the material components of the reactor. Thus, the evaluation of the structure integrity can be underway with actual material mechanical properties.

\section{EXPERIMENTAL METHOD}

\section{Materials and Equipment}

Currently, there are variety of products of nuclear grade graphite, such as PGX, IG-110 and ASR-ORB [3]. In this study, IG-110 (product of Toyo Tanso co., Ltd.) was selected. Table 1 shows the important properties of IG-110 graphite as considerations for use as a HTGR type reactor core material [3]. There are two types of specimens used in the study. The first type is a block type with a size $35 \times 35 \times 55[\mathrm{~mm}]$ which was used for

Table 1. Thermal and mechanical properties of graphite IG-110

\begin{tabular}{|c|c|}
\hline Material properties & Value \\
\hline Density $\left[\mathrm{kg} / \mathrm{m}^{3}\right](300 \mathrm{~K})$ & 1,780 \\
\hline Average strong tensile $(\mathrm{MPa})(300 \mathrm{~K})$ & 25.3 \\
\hline Average strong press $(\mathrm{MPa})(300 \mathrm{~K})$ & 76.8 \\
\hline Modulus of elasticity (GPa) $(300 \mathrm{~K})$ & 7.9 \\
\hline Ave. expansion coefficient $(293-673 \mathrm{~K})\left(10^{6 /} \mathrm{K}\right)$ & 4.06 \\
\hline Thermal conductivity $(\mathrm{w} /(\mathrm{mK}))(600 \mathrm{~K})$ & 80 \\
\hline Ash (ppm) & Max.100 \\
\hline Grain size $(\mu \mathrm{m})$ & Rer. 20 \\
\hline
\end{tabular}


non-destructive inspection specimen. The second type is a cube spesimen with a size of $10 \times 10 \times 10$ [mm] used for compressive test as a verification of non-destructive inspection results. In order to verify the level of isotropic of graphite material, 3 specimens were used with the same size and were made from the same block but with different orientation of the length size. Figure 1 shows the schematical view of where each specimen came from.

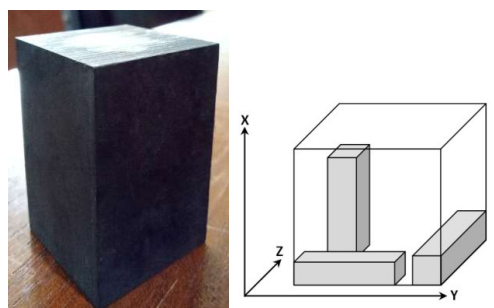

Figure 1. Specimens and the position of material were taken.

In order to enhance the ultrasonic transmission from transducer to the specimens, the surface of each specimen was polished using sandpaper with a degree of roughness up to \#600. As an identification, each specimen was named to the position in cartesian coordinate lengthwise as shown in Figure 1, so that the specimen was named $\mathrm{X}, \mathrm{Y}$ and $\mathrm{Z}$. The equipment used in this work is the Ultrasonic Flaw Detector (UFD) EPOCH 4 Plus. This equipment is at once can serve as a pulser and receiver of ultrasonic wave signal. Each of the two transducers emits longitudinal and transversal ultrasonic wave modes. Each transducer has the same frequency of $5 \mathrm{MHz}$. Beside through sanding, to increase the effectiveness of the ultrasonic wave propagation from the transducer to the graphite materials, vaseline couplant was used.

\section{Propagation Measurment}

Firstly, the UFD equipment was calibrated by using step wedges as shown in Figure 2. The calibration was done to ensure that the equipment is in good condition, especially in terms of linearity the reading at the time coordinate (horizontal). After that, to determine the modulus of elasticity of the graphite material, two parameters: ultrasonic wave propagation distance and time required for ultrasound waves propagate were set. Measurement of propagation distance was conducted by measuring the block specimens with size of $35 \times 35 \times 55[\mathrm{~mm}]$ which has been smoothened using sandpaper. The propagation time is measured using a UFD with two types of transducer that are longitudinal and transversal transducers. Each specimen is

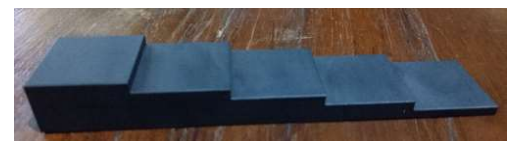

Figure 2. Step wedges for calibration. smoothened on two surfaces (planes). For instance, for specimen 1 (the longest dimension is in X-axis), then the measurement of the specimen with each transducer is conducted on the $\mathrm{Y}$ and the $\mathrm{Z}$ plane. Specimen 2 and 3, the longest dimension is in $\mathrm{Y}$ and $\mathrm{Z}$ axis respectively. In addition, three measurements were conducted at the different points for each surface. The propagation distance (specimen size) was measured using micrometer.

Based on the measurements results of distance and time, calculations were done to determine the propagation velocity of each ultrasonic wave by using the following equation [4].

$$
V_{L, S}=\frac{2 d}{\mathrm{TOF}}
$$

with:

$$
\begin{aligned}
V_{L, S}= & \text { Uultrasonic wave propagation velocity } \\
& \text { (transversal or longitudinal) } \\
d= & \text { The propagation distance which are the } \\
& \text { measured specimens lateral planes, and } \\
\mathrm{TOF}= & \text { (time of flight) is the time of propagation }
\end{aligned}
$$

Furthermore, the results of the propagation velocity calculations of both types of ultrasonic waves, calculation of the modulus of elasticity were carried out using the following equations [4].

$$
E=\rho V_{s}^{2} \frac{\left(3 V_{L}^{2}-4 V_{S}^{2}\right)}{V_{L}^{2}-V_{S}^{2}}
$$

with:

$\rho=$ The material density

$V_{L}$ and $V_{S}=$ The propagation velocity of longitudinal and transversal waves, respectively

In order to validate the value of the modulus of elasticity obtained by non-destructive inspection, compressive tests were conducted by using cube specimen. The tests were conducted using the Universal Tensile Machine with a capacity of $150 \mathrm{kN}$. Testing were conducted with cross head movement control with a speed of $0.5 \mathrm{~mm} / \mathrm{min}$ [12]. Compressive tests were conducted by using 3 specimens.

\section{RESULTS AND DISCUSSIONS}

The signal test result shows the ultrasonic wave signals on ultrasonic wave inspections in graphite material (Figure 3). In the ultrasonic inspection of pulse echo method, the signal is displayed on the screen in the form of initial ultrasonic waves pulse and reflected wave signals. In Figure 3(a), the first signal is initiating pulse, the second signal is the first reflected wave and third signal is the second reflected wave. Based on the difference of the first reflected wave signal and the second one, the attenuation value of ultrasonic wave was known by comparing the signal amplitude. In Figure 3 , with setup of the Gain by $49.6 \mathrm{~dB}$, the first reflected 

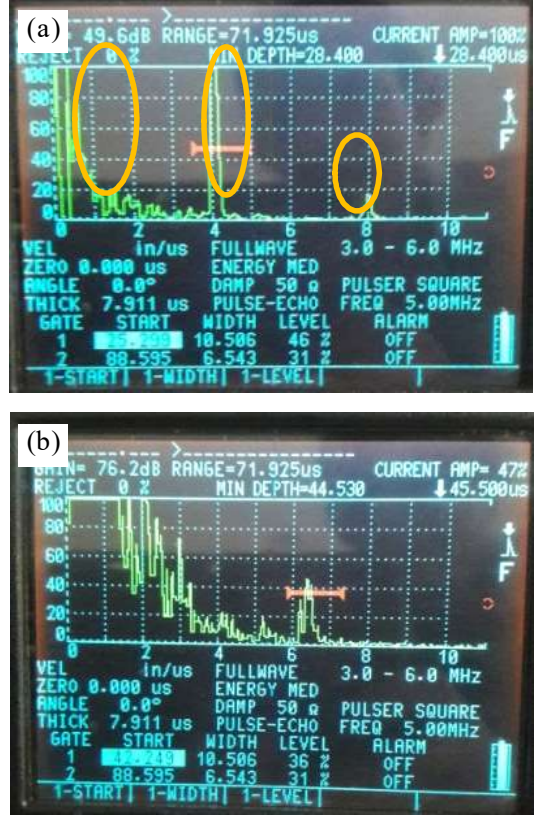

Figure 3. Typical test signal for graphite material (a). high gain, (b). low gain.

signal amplitude is over than $100 \%$, while the second one is about $18 \%$. It shows that graphite material has a large attenuation value. The propagation time of ultrasonic wave is determined by distance of the first reflected signal and the second one in the time axis (horizontal axis).

Figure 3(b) shows the signals when the ultrasonic probe directed into thicker specimen with a higher Gain setup $(76.2 \mathrm{~dB})$. Thus, the ultrasonic wave needs more time for travelling along the specimen. It resulted the first reflected wave arises delayed compare to the Fig. 3 (a) and the amplitude of the signal is lower (47\%).

Table 2 shows the results of the propagation velocity measurement of longitudinal and transversal ultrasonic wave from three specimens. The results in this table represent the entire direction of the coordinate axes of the specimen and the mean value of the three times measurement are presented. According to the results of these measurements, it can be seen that the value of longitudinal wave propagation velocity is greater than the transversal wave. Focusing on the standard deviation value of each measurement, measurement results showed good consistency, except for three

Table 2. The results of the measurement of ultrasonic wave propagation velocity for graphite IG-110

\begin{tabular}{cccrcr}
\hline $\begin{array}{c}\text { Specime } \\
\text { n ID }\end{array}$ & Plane & $\begin{array}{c}\text { Longitudinal } \\
\text { m/s (Mean) }\end{array}$ & Stdev. & $\begin{array}{c}\text { Transversal } \\
\text { m/s (Mean) }\end{array}$ & Stdev. \\
\hline \multirow{2}{*}{$\mathrm{X}$} & $\mathrm{Y}$ & 2314.20 & 5.91 & 1503.96 & 6.22 \\
& $\mathrm{Z}$ & 2308.18 & 0.44 & 1483.51 & 3.43 \\
\hline \multirow{2}{*}{$\mathrm{Y}$} & $\mathrm{Z}$ & 2318.40 & 10.60 & 1524.53 & 5.61 \\
& $\mathrm{X}$ & 2329.92 & 10.39 & 1531.08 & 9.91 \\
\hline \multirow{2}{*}{$\mathrm{Z}$} & $\mathrm{X}$ & 2321.82 & 6.17 & 1499.02 & 10.96 \\
& $\mathrm{Y}$ & 2319.16 & 7.90 & 1490.15 & 3.73 \\
\hline \multicolumn{2}{r}{ Mean } & 2318.61 & & 1505.37 & \\
\hline \multicolumn{2}{r}{ Stdev. } & 7.31 & & 18.87 & \\
\hline
\end{tabular}

measurements with standard deviation approximately 10 . Small standard deviation value is resulted by both of equipment factor and graphite homogeneity. By comparing the measurement results on each direction of the coordinate axes which has a small standard deviation, it can be concluded that the graphite material IG-110 has ideal isotropic characteristics. Isotropic characteristics of this graphite material can be obtained in the manufacturing process using isopressure method.

Figure 4 shows the calculation results of modulus of elasticity based on the propagation time measurements results using ultrasonic method as shown in Table 2 using equations (1) and (2). The notation X, Y and $\mathrm{Z}$ indicate the value of the modulus of elasticity in direction of the coordinate axes X, Y, and Z. In Fig.4, Modulus of Elasticity in specimen 1 was measured in $Y$ and $\mathrm{Z}$ direction, in specimen 2 was measured in $\mathrm{Z}$ and $\mathrm{X}$ direction, and in specimen 3 was measured in $\mathrm{Y}$ and $\mathrm{X}$ direction, respectively. Modulus of elasticity values show a consistent approach results as shown in table 2 . When a modulus of elasticity values in Figure 4 compared to the mechanical properties shown in table 1 (the value of the modulus of elasticity is $7.8 \mathrm{GPa}$ ), there is a difference of $1.1 \mathrm{GPa}$ or equivalent to $14 \%$. However, since the mechanical properties of a material are vary, then it is needed to verify these results by comparing with the results from the compressive test.

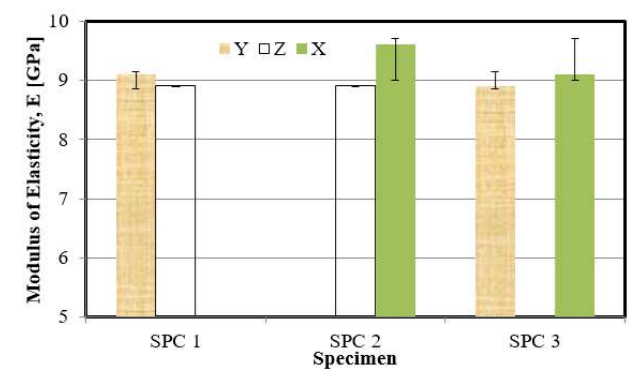

Figure 4. Calculation results of elasticity modulus measurement based on ultrasonic waves propagation.

Figure 5 shows the relationship between the load in the vertical axis and displacement of cross head in horizontal axis resulted from compressive test of IG-110 graphite. The compressive strength and modulus of elasticity can be determined by this graph. The compressive strength is indicated by the maximum load subjected to the test divided by specimen area where the load subjected. The modulus of elasticity is determined by the slope or gradient of the straight line in the graph by the following procedure. The force in vertical axis is converted into Stress $\left(\mathrm{N} / \mathrm{mm}^{2}\right)$ and the displacement in the horizontal axis is divided by original specimen's size to get strain. Then, the modulus of elasticity is stress divided by strain[13]. All of these graphs in Figure 5 show a similar maximum force and the slope. 

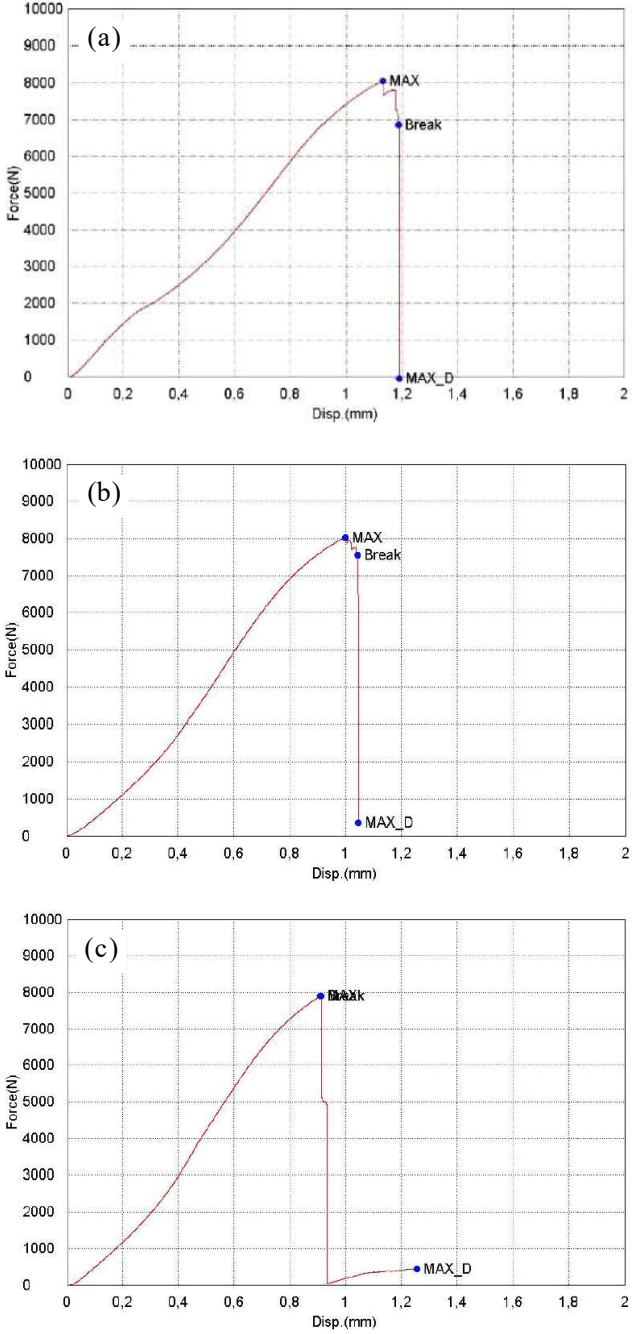

Figure 5. Graph of compressive test on IG-110 graphite material

Figure 6 shows the compressive strength resulted in current work. In the same time, the compressive strength of IG-110 graphite resulted from the previous studies are plotted in the same graph. By comparing these results, it can be considered that there is indeed a distribution of material's mechanical properties, in this case, the value of compressive strength. In this comparison, the compressive strength value in the current work is among the compressive

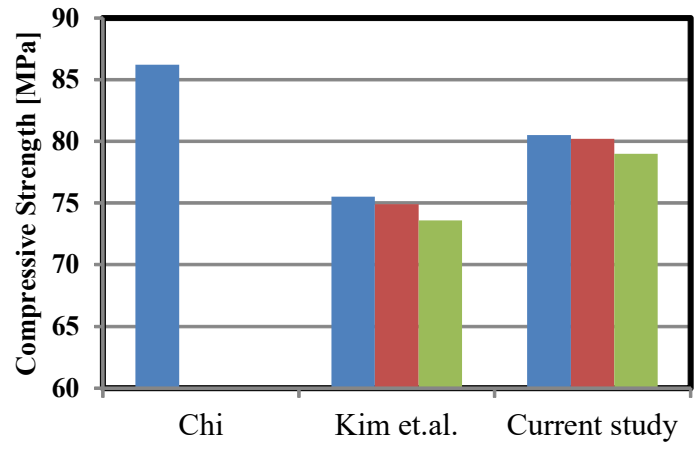

Figure 6. Comparison of press test resuts $[12,14]$. strength values by Chi and Kim, et. al. [12,14]. According to this graph, it can be confirmed that the compressive tests in the current work has been validated.

Based on the graph of compressive test in Figure 5 , by determining the slope of the straight line, the modulus of elasticity is $10.2 \mathrm{GPa}$ (average value of 3 tests). When this value is compared to the value of the modulus of elasticity resulted from ultrasonic inspection, that is $9.1 \mathrm{GPa}$ (averaged value of 6 tests in Fig. 4), then the results, between destructive and nondestructive tests, there is a difference of $1.1 \mathrm{GPa}$. If the destructive test results made into the reference value, then the non-destructive test results are approximately $10 \%$ smaller than the value of destructive test results. These differences indicate that the non-destructive method can be used as a method for predicting the modulus of elasticity of IG-110 graphite[4,8]. As mentioned in previous part, the non-destructive testing with ultrasonic method was performed by using Ultrasonic Flaw Detector that has a low level of precision to measure the ultrasonic propagation time. Thus, in order to minimize the difference between the value of the destructive and non-destructive tests, it is recommended to use a high precision ultrasonic equipment in the measuring the ultrasonic propagation time.

\section{CONCLUSIONS}

The non-destructive test has been conducted against the IG-110 graphite using Ultrasonic Flaw Detector. The test aims to predict isotropic mechanical properties and the modulus of elasticity value. From the test results using the 3 specimens, the isotropic properties can be shown from the results of ultrasonic (longitudinal and transverse) propagation and direction of the coordinate axes with a value of standard deviation below 10 . While the value of the modulus of elasticity of the non-destructive test is 9.1 $\mathrm{GPa}$. This value is approximately $10 \%$ lower than the value that was resulted on the press test. The nondestructive method using ultrasonic waves can be used to estimate/predict the isotropic characteristics and the value of the modulus of elasticity of IG-110 graphite material.

\section{ACKNOWLEDGEMENT}

This work has been carried out as a key technology development study for the Experimental Power Reactor project. Financially support by PTKRN 2018 budget and by Ministry of Research and Technology and Higher Education (Kemenristekdikti) through the INSINAS FLAGSHIP BATAN program with contract number $01 /$ INS-1/PPK/E4/2018 are acknowledged. 


\section{REFERENCES}

[1]. H. Sekimoto, A brief history of design studies on innovative nuclear reactors, AIP Conf. Proc. 1615 (2014) 3-9.

[2]. A. Tzelepi, P. Ramsay, A.G. Steer, J. Dinsdale-Potter, Measuring the fracture properties of irradiated reactor core graphite, J. Nucl. Mater. 509 (2018) 667-678.

[3]. X.W. Zhou, Y.P. Tang, Z.M. Lu, J. Zhang, B. Liu, Nuclear graphite for high temperature gas-cooled reactors, Xinxing Tan Cailiao/New Carbon Mater. 32 (2017) 193-204.

[4]. D. Souri, Ultrasonic velocities, elastic modulus and hardness of ternary Sb-V2O5-TeO2glasses, J. Non. Cryst. Solids. 470 (2017) 112-121.

[5]. C.L. Nogueira, K.L. Rens, Ultrasonic wave propagation in EPS lightweight concrete and effective elastic properties, Constr. Build. Mater. 184(2018) 634-642.

[6]. K. Kese, P.A.T. Olsson, A.M. Alvarez Holston, E. Broitman, High temperature nanoindentation hardness and Young's modulus measurement in a neutron-irradiated fuel cladding material, J. Nucl. Mater. 487 (2017) 113-120.

[7]. X. Dai, Q. Cao, H. Xie, Characterization for Young's modulus of TBCs using soft lithography gratings and moiré interferometry, Meas. J. Int. Meas. Confed. 122 (2018) 201-211.
[8]. M. Musiał, J. Grosel, Determining the Young's modulus of concrete by measuring the eigenfrequencies of concrete and reinforced concrete beams, Constr. Build. Mater. 121 (2016) 44-52.

[9]. R.J.M. Wolfs, F.P. Bos, T.A.M. Salet, Correlation between destructive compression tests and nondestructive ultrasonic measurements on early age 3D printed concrete, Constr. Build. Mater. 181 (2018) 447-454.

[10]. Y. Zhang, P.Y. Ben Jar, K.C.T. Nguyen, L.H. Le, Characterization of ductile damage in polyethylene plate using ultrasonic testing, Polym. Test. 62 (2017) 51-60.

[11]. T. Mandal, J.M. Tinjum, T.B. Edil, Non-destructive testing of cementitiously stabilized materials using ultrasonic pulse velocity test, Transp. Geotech. 6 (2016) 97-107.

[12]. J. Kim, Y. Lee, J. Kim, Y. Yoon, High Temperature Compressive Test of Nuclear Graphite IG-110, (2010) 407-408.

[13]. F. Cornacchia, T. Liu, Y. Bai, N. Fantuzzi, Tensile strength of the unbonded flexible pipes, Compos. Struct. 218 (2019) 142-151.

[14]. S. Chi, Specimen size effects on the compressive strength and Weibull modulus of nuclear graphite of different coke particle size/ : IG-110 and NBG-18, J. Nucl. Mater. 436 (2013) 185-190. 